\title{
Megemlékezés Dr. SzÉKY PÁL (1924-2016) munkásságáról
}

\author{
KISS ISTVÁN és BAKONYI GÁBOR \\ Szent István Egyetem, Mezőgazdaság- és Környezettudományi Kar, \\ Állattani és Állatökológiai Tanszék, 2100 Gödöllö, Páter K. u. 1. \\ E-mail: Kiss.Istvan@mkk.szie.hu,Bakonyi.Gabor@mkk.szie.hu
}

2016. november 3-án, 92 éves korában, hosszú betegeskedés után elhunyt dr. SzÉKY PÁL ny. egyetemi docens, a Szent István Egyetem oktatója (1. ábra).

SzÉKY PÁl 1924. július 29-én született Pécsett. Édesanyja (VLASITS ETELKA) háztartásbeli, apja (SZÉKY PÁL) tanár volt. Apjának egyik ismert publikációja a katolikus elemi népiskolák V-VI. osztálya számára íródott „Vegytan, Természettan, címü, 1936-ban megjelent tankönyv, amelynek társszerzője volt.

Az apai indíttatás nem csak SzÉKY PÁL életét, de mindkét nővérét is a pedagógusi pályára állította. Elemi és középiskolai tanulmányait Pécsett végezte. Az öt éves pécsi tanítóképző elvégzését (1943) követően tanítói oklevelet szerzett. Mivel érdeklődése már ekkor az állatbiológia iránt mutatkozott, munkahelyi felvételét kérte az Állatorvosi Föiskolára, majd a Mezőgazdasági Főiskolára, de nem vették fel, mert csak tanítói oklevele volt. Állami szolgálatát ideiglenes minősítésü, tiszteletdíjas tanítóként a Tatai Téli Gazdasági Iskolában kezdhette el 1943-ban.

1. ábra. Dr. SZÉKY PÁL (1924-2016).

Figure 1. Dr. PÁL SZÉKY (1924-2016).

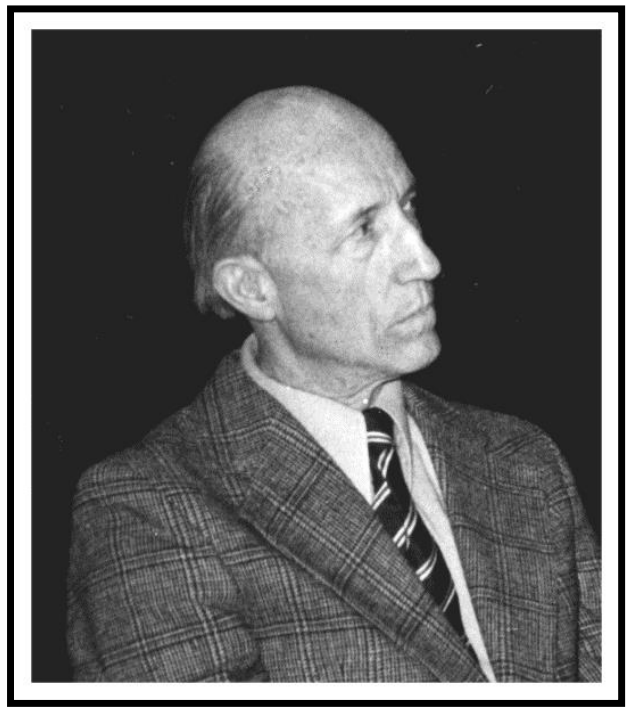

Ugyanitt egy év múlva már helyettes tanító volt. 1944-ben felvételt nyert a Mosonmagyaróvári Mezőgazdasági föiskolára, de tanulmányait a háborús események miatt csak 1945 öszén, a hadifogságból szabadulva folytathatta. Közben áthelyezték a Móri Gazdaképző Iskolába (1945-1946), majd 1946-1948 között a Mosonmagyaróvári Gazdaképző Iskolába, helyettes tanítónak. A Magyar Agrártudományi Egyetemet 1948-ban elvégezte okleveles mezőgazdaként, majd rögtön Keszthelyre került egy gazdasági tanári tanfolyamra. 1948-tól

* Előadták a szerzők a MBT Állattani Szakosztály 1036. ülésén, 2016. december 7-én. 
1949-ig az Ádándi Gazdaképző Iskolában, 1949-ben a Kecskeméti Mezőgazdasági Középiskolában, majd 1949-1950-ben a Zsámbéki Mezőgazdasági Akadémián, mint gazdasági tanár oktatott. Útja innen a Budapesti Agrártudományi Egyetemre vezetett, ahol 1950-1955 között tanársegédi, majd 1959-ig adjunktusi beosztást kapott. Kezdetben az Agrobiológiai Tanszéken, 1952-től az Állatélettani, majd 1954-ben az Állattani Tanszéken dolgozott (2. ábra). A Gödöllői Agrártudományi Egyetem megalakulásától, 1959-től egészen 1977-ig adjunktusként oktatott, majd 1978-tól egyetemi docensi kinevezést kapott. Jól beszélt németül, de angol és orosz nyelven is tudta olvasni a szakirodalmat. A Gödöllői Agrártudományi Egyetemen több mint három évtizedes oktató-nevelö és tudományos kutató munka után, 1982-ben nyugdíjba vonult.

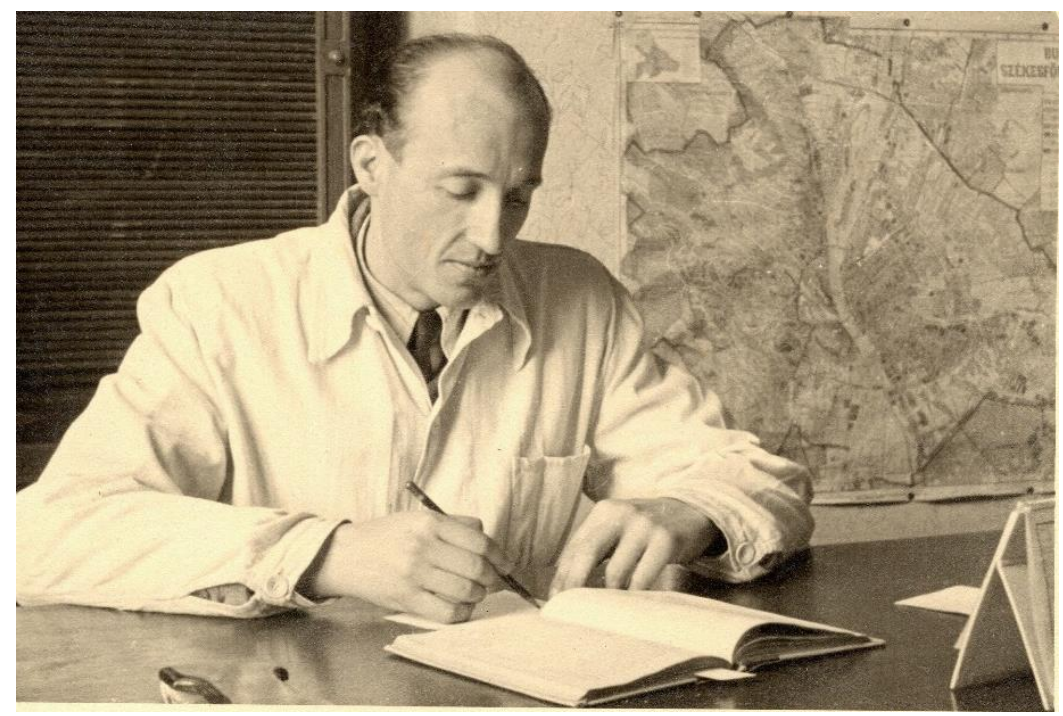

2. ábra. A fiatal oktató, SzÉKY PÁL az 1960-as évek közepén a Budapesti Agrártudományi Egyetemen.

Figure 2. The young university teacher, PÁL SzÉKY at the Agricultural University of Budapest in the middle of the 1960s.

Oktatási tevékenysége kezdetben elsősorban a gyakorlati oktatásban, később az előadások tartásában is megvalósult. Számos tantárgyat tanított. Szigorú, következetes, de korrekt, segítőkész oktatóként ismerhették meg a hallgatók. A képzés szinte minden lépcsőfokába bekapcsolódott. Tartott egyetemi előkészítő tanfolyamokat, részt vett a szakmunkás képzésben, valamint az egyetemi nappalos, levelező és a szakmérnöki képzés több formájában. Hosszú éveken át nevelőtanári megbízása volt az első és másodéves hallgatói csoportoknál. Meghatározó szerepet töltött be az országban először Gödöllőn létrehozott halgazdálkodási szakmérnök képzésben. A halbiológia területén olyan tananyagot alakított ki, amely évtizedeken keresztül a hazai valamennyi ilyen irányú képzés vázát adta. Mindezen területeken jegyzetek, tankönyvek és szakkönyvek érlelődtek ki keze alól. Egyetemi jegyzeteinek és 
tankönyveinek száma 25. Emeljük ki ezek közül a „Halak anatómiája és élettana” című egyetemi jegyzetet (1963), amelyben 62 ábrát saját kezüleg rajzolt meg. Ebből a munkából teljesedett ki a „Halak élete” címü könyve (1967), amely évtizedeken át az egyetlen magyar nyelven hozzáférhetö összegzését adta a halak testfelépítésének és élettanának. Az „Állattan" címü tankönyvnek, mely a hazai agráregyetemeken oktatott állattani ismereteknek kötelező tananyagává vált, több fejezetét írta. A tankönyv 1965-ös első megjelenését követően több javított és bővített kiadása $(1973,1977)$ jelent meg. Nagy hangsúlyt fektetett az oktatás szemléltető anyagainak állandó fejlesztésére. Az oktatás korszerúsítésére kiírt egyetemi pályázaton a legjobb eredményt érte el 1973-ban. A Természettudományi Múzeum Állattára kutatóival rendszeresen vett részt hazai gyüjtőutakon, ahol a tanszék részére is igen sok szemléltető anyagot szerzett be (3. és 4. ábra). Kutatómunkájához kapcsolódóan igen értékes koponya és csontvázanyagot, valamint röntgenfelvétel gyüjteményt állított össze.

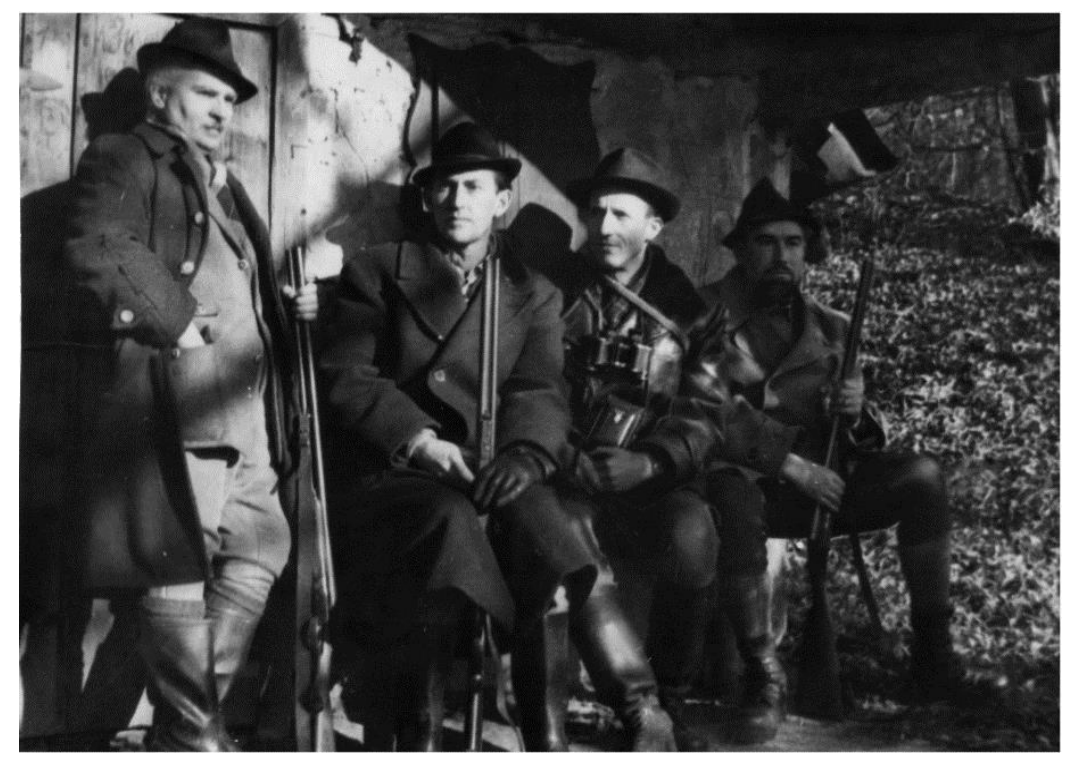

3. ábra. Gyüjtőúton a Börzsönyben (1961). (Bal szélen SzABÓ IsTVÁN, balról a harmadik SZÉKY PÁL, a jobb szélen JANISCH MIKLÓS)

Figure 3. Zoological excursion in the Börzsöny Mountain (1961). (IsTVÁN SzABÓ at the left side, PÁL SZÉKY third from the left, MIKLÓS JANISCH at the right.)

Példátlan lelkesedéssel képezte önmagát. Nyaranta, több éven át különböző biológus és módszertani tanfolyamokat végzett el a Tihanyi Biológiai Kutató Intézetben (1958-1960, 1962). Itt ismerkedett meg FÁBIÁN GYULÁval, akinek genetikai kutatásaiba is bekapcsolódott. Részt vett polarográfiás (1952), fotólaboráns (1952/53), elektronmikroszkóp (1961), keskenyfilmezés (1962/63), tudományos filmezési (1964) és matematikai (1967) továbbképző tanfolyamokon. Az Állatorvosi Főiskolán (1950/51) ,,anatómiát és élettant”, az Eötvös Loránd Tudományegyetemen (1958/59) „,zoológiát”, a Budapesti Orvostudományi 
Egyetemen (1958/59) „radiológiát” hallgatott 1-2 szemeszteren át, mint vendéghallgató. Levelező úton gazdasági tanári képesítést is szerzett az Agrártudományi Egyetem Továbbképző Intézet Tanárképző Szakán (1956-1958).

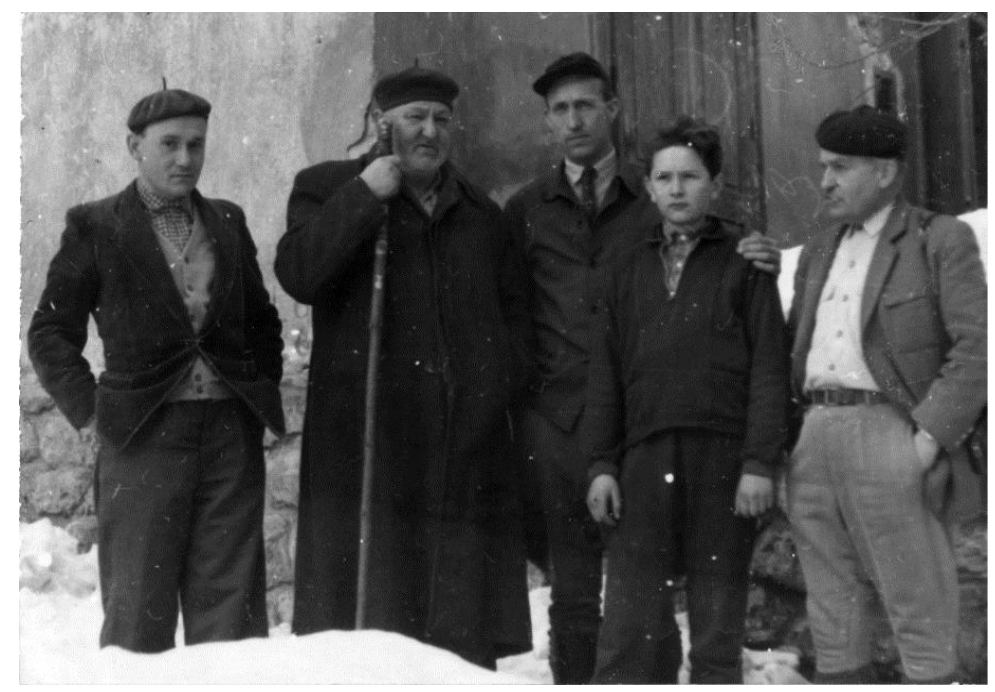

4. ábra. Tanulmányúton a Bükkben (1963). (Bal szélen TOPÁL GYÖRGY, mellette VÁSÁrHelyi ISTVÁN, SZÉKY PÁL, VÁSÁRHELYI I. fia, jobb szélen SZABÓ ISTVÁN)

Figure 4. Field trip in the Bükk Mountain (1963). (GYÖRGY TOPÁL, ISTVÁN VÁSÁRHELYI, PÁL SZÉKY, son of ISTVÁN VÁSÁRHELYI, ISTVÁN SZABÓ, from left to right.)

A Gödöllői Agrártudományi Egyetem Állattani Tanszékén kezdetben halhaematológiai vizsgálatokban vett részt, majd később a halak növekedésvizsgálatával foglalkozott. Egyetemi doktori címét 1961-ben e témában védte meg. Mivel a Kar akkori vezetése e téma további folytatását nem támogatta, 1962-től ragadozó kisemlösök morfogenezisével kezdett el foglalkozni. Többszöri sikertelen aspirantúrára jelentkezést követően a 10 éves kutatás eredményeiből végül elkészíthette és 1972-ben megvédte disszertációját, amivel elnyerte a biológiai tudományok kandidátusa tudományos fokozatot. Kutatásai során mindig kitünt az új, gyakran meglepő módszerek bevezetésével, ami nagyban hozzásegítette eredményességéhez. Szoros kutatási együttmüködéseket tartott fenn például a Szarvasi Haltenyésztési Kutatóintézettel, az MTA Genetikai kutatócsoporttal, a Magyar Természettudományi Múzeum Állattárával, a Magyar Földtani Intézettel. Bekapcsolódott az országos apróvadgazdálkodási, később az ökológiai tárgyú kutatásokba. Komoly szerepe volt Gödöllő környékének zoológiai feltárásában. Tudományos cikkeinek száma 38, melyek egy része nívós külföldi folyóiratban jelent meg, ami az akkori időkben elismerést váltott ki.

Az oktatás és kutatás időigényén túl, ismerve a saját magával szemben támasztott szigorú követelményeket, szinte emberfeletti az, hogyan vált a zoológia tudományát népszerüsítő szakíróvá. Megjelent 26 könyve, illetve könyvrészlete, és 228 népszerüsítő írása! Könyv- 
részletei közül kiemelkedik a FÁBIÁN GYULA által szerkesztett „Phaenoanalysis and Quantitative Inheritance" (1969) címü könyv, amely nemzetközi ismertséghez vezette. Széles látóköre és tájékozottsága révén olyan tudományterületek bemutatását is magára vállalta, amelyek magyar nyelven azideig nem álltak az olvasók rendelkezésére. Ez alkalmanként együtt járt azzal, hogy a hazai kutatók véleményét is megosztotta. Népszerüsítő művei közül említsük meg például a „Korunk környezetbiológiája” (1977), az „Ökológia” (1977), az „Etológia” (1977), és az „Ökológiai kislexikon” (1983). című könyveket, amelyeken több nemzedék fiatal érdeklődői nőttek fel. Tizenkét könyvrészlete jelent meg az orvosoknak és biológusoknak szánt „Biológia aktuális problémái” kiadványsorozatban. Ismeretterjesztő cikkei elsősorban a Természet világa (+Természettudományi Közlöny) (97), a Halászat (54), a Búvár (+TermészetBúvár) (22), a Magyar Horgász (9) és az Élet és Tudomány (7) folyóiratokban láttak napvilágot. E mellett időt szakított több könyv lefordítására is. Oktató munkájában a tananyagfejlesztés fontos szerepet kapott, 20 tankönyv, egyetemi jegyzet és oktatási anyag egyedüli- vagy társszerzője.

A szakmai közéletben tevékenyen részt vett. Tagja volt a Pedagógus Társaságnak, a TIT-nek, a Magyar Biológiai Társaságnak. Munkatársa lett a Természet Világa szerkesztő bizottságának. Az Egyetem és a Kar munkájában is fontos szerepet játszott. Titkára volt a Müszerügyi és Filmbizottságnak, tagja a Kari Nevelési Bizottságnak, az Egyetemi Oktatási és Oktatástechnikai Bizottságnak és az Egyetemi Tanácsnak. 1978-ban a Mezőgazdaságtudományi Karon három évre kutatási dékánhelyettesi megbízást kapott. Egyetemi munkájának elismeréseként 1958-ban és 1976-ban a „Mezőgazdaság kiváló dolgozója” címet, 1982-ben a „Kiváló munkáért” miniszteri kitüntetést kapta meg.

1954-ben nősült meg. Felesége, HARSÁNYI EDIT orvos-laboráns végzettségü, aki nyugdíjba vonulásáig a Gödöllői ATE Elektronmikroszkóp Laboratóriumában dolgozott. Két fiúgyermekük van; PÁL PÉTER 1955-ben, TAMÁs 1965-ben született.

Egykori munkahelyi vezetöje, FÁBIÁN GYULA professzor róla készített véleménye jól tükrözi SzÉKY PÁL tanszéki és szakmai közéletben betöltött szerepét:

„A jövő munkájára vonatkozóan igyekezzen túl szerény és visszahúzódó magatartását nagyobb önbizalomra váltani és tudományos nézeteit a tanszék keretein túl is harcosan képviselni." (1971)

„Véleményem szerint a tanszéki oktatók közül fokozatosan az elsö helyre került a kutatási módszerek változatosságát és széles körét tekintve." (1973)

SzÉKY PÁL az oktatói foglalkozását mindvégig hivatásnak tartotta és e szerint művelte. Az egyetemi munkahelyén számos oktatónak volt szakmai mentora, népszerüsítő könyvei és írásai nemzedékeknek nyújtott betekintést a zoológia aktuális és érdekes területeibe.

Nyugodjék békében! 


\title{
Commemoration of the work of dr. PÁL SzÉKY (1924-2016)
}

\section{ISTVÁN KISS \& GÁBOR BAKONYI}

\author{
Szent István University, Department of Zoology and Animal Ecology, \\ Páter K. u. 1., H-2100 Gödöllő, Hungary \\ E-mail: Kiss.Istvan@mkk.szie.hu,Bakonyi.Gabor@mkk.szie.hu
}

ÁLLATTANI KÖZLEMÉNYEK (2017) 102(1-2): 51-69.

\begin{abstract}
Dr. PÁL SZÉKY associate professor at the Szent István University, Department of Zoology and Animal Ecology passed away at age 92. He took his diplom with a college degree at the Hungarian Agricultural University in 1948. He taught zoology and ecology at the Agricultural University of Budapest from 1950 to 1959 and the Agricultural University of Gödöllő from 1959 to 1982. His field of research was fish biology and hematology at the beginning of his research activity. Fish biology was the subject of his dr. Univ. thesis. The postgraduate specialist training course of fish farming was established in Gödöllö, in which he had a decisive role. He also developed a curriculum for fish biology, which was used at several training levels. In 1972 he gained the candidate of sciences (CSc) degree based on his work on the morphogenesis of vertebrates. PÁL SzÉKY published 38 scientific papers and 20 lecture notes and textbooks. The best known of these is the „Zoology" book written for students of agriculture. This book was used for decades at the agricultural universities in Hungary. He was an excellent popular science writer too publishing 26 books and 228 papers of this kind.
\end{abstract}

Keywords: publication list, curriculum vitae, zoologist. 


\section{Dr. SzÉKY PÁL munkássága Publications by dr. PÁl SzÉKY}

\section{Tudományos cikkek}

FÁBIÁN, Gy., IvÁNYI, P. \& SzÉKy, P. (1963): Skin Transplantation in Partially Inbred Rabbits. Folia Biologica 9: 440-443.

FÁbián, Gy., Précsényi, I., Széky, P., BAKonyi, G., MolnáR, E., Melko, E. \& Nosek, J. (1977): Stabil 15-N izotóp áramlásának nyomonkövetése egy természetes homokpusztai gyep biocönózisában. Agrártudományi Egyetem Közleményei 5-12.

FÁbián, Gy., Précsényi, I., Széky, P., Bakonyi, G., Molnár, E., Nosek, J. \& Melkó, E. (1979): Investigations of $15-\mathrm{N}$ flow in a sandy grassland community. (Tece studies No. 14.). Annales Universitatis Scientiarum Budapestinensis de Rolando Eötvös Nominatae. Sectio biologica 2021: 17-30.

FÁBIÁN, Gy. \& SzÉKY, P. (1954): Examinations of blood catalase in a hybridisation experiment with rabbits. Acta Biologica 1-2: 119-130.

HAVASI, A. \& SzÉKY, P. (1991): Descriptive and comparative osteology of Stone Marten and Pine Marten. In: CSÁNYI, S. \& ERnHAFT, J. (eds): Transactions of the XXth Congress of the International Union of Game Biologists, Gödöllö, Hungary, August 21-26, University of Agricultural Sciences Vol. II. pp. 558-564.

Heltay, I. \& SzÉKY, P. (1975): Populáció-dinamikai vizsgálatok mezeinyúlnál. A Vadgazdálkodás Fejlesztése (MÉM-Kiadvány) 15: 5-41.

MolnÁR, Gy, SzÉKy, P. \& NAGY, E. (1955): Haematológiai vizsgálatok nyurgapontyon. Agrártudományi Egyetem Állattenyésztési Karának Közleményei 9: 3-15.

MolNÁR, Gy., SzÉKY, P. \& NAGY, E. (1956): Haematológiai vizsgálatok egészséges pontyokon (Cyprinus carpio L.). Haltenyésztési Kutató Intézet Évkönyve 2: 417-440.

MolNÁR, GY., SzÉKY, P. \& NAGY, E. (1956): Két és háromnyaras pontyok haematológiai vizsgálata. Agrártudományi Egyetem Állattenyésztési Karának Közleményei 4: 209-220.

MolnÁr, Gy., SzÉKY, P. \& NAGY, E. (1959): Haematológiai vizsgálatok balatoni fogassüllőn (Lucioperca sandra Cuvier) és dévér keszegen (Abramis brama L.). A Magyar Tudományos Akadémia Tihanyi Biológiai Kutató Intézetének Évkönyve 26: 51-68.

MolnÁR, Gy., SzÉKY, P. \& NAGY, E. (1959): Haematologische Untersuchungen an dem im Balaton vorkommenden Zandern (Lucioperca lucioperca L.) und Bleien (Abramis brama L.). Acta Biologica 10(2): 223-234.

MolNÁR, GY., SzÉKY, P. \& NAGY, E. (1961): Röntgen-módszer felhasználása az alkalmazott zoológiai kutatásokban. Agrártudományi Egyetem Mezögazdaságtudományi Karának Közleményei 1: 27-34.

SINKOVITSNÉ HLUBIK, I. \& SZÉKY, P. (1967): Néhány hazai ragadozó emlős haematológiai vizsgálata. Állattani Közlemények 54(1-4): 139-145.

SRÉTER, F., BARNA, J., HunYADI, E. \& SzÉKY, P. (1954): Időszaki változások a szarvasmarhaszérum karotin-, A-vitamin-, anorganikus foszfor- és kalciumszintjében. Állattenyésztés 3(4): 315-324.

SRÉTER, F. \& SZÉKY, P. (1955): Vérkataláz és májfunkciós vizsgálatok magyar tarka marhákon. Agrártudományi Egyetem Állattenyésztési Karának Közleményei 9: 29-39.

SRÉTER, F. \& SzÉKY, P. (1956): Májfunkciós és vérkatalázaktivitás vizsgálatok izommunka alkalmával. Agrártudományi Egyetem Állattenyésztési Karának Közleményei 6: 305-313. 
SzÉKY, P. (1955): Vérkataláz-aktivitás vizsgálatok nyulakon. Agrártudományi Egyetem Állattenyésztési Karának Közleményei 9: 17-26.

SzÉKY, P. (1960): A polarográfia elvi alapjai és a kísérleti biológiában való felhasználásának lehetőségei. A Magyar Tudományos Akadémia Biológiai Csoportjának közleményei 4(3-4): 297-314.

SzÉKY, P. (1960): A polarográfia és felhasználásának lehetőségei a hidrobiológiában. Hidrológiai Közlöny 40(4): 337-341.

SzÉKY, P. (1960): A polarográfia lényege és a mezőgazdasági kutatásokban való felhasználásának lehetőségei. Agrártudományi Egyetem Mezögazdaságtudományi Karának Közleményei 29-36.

SzÉKY, P. (1962): A halak postembrionális növekedésének vizsgálata röntgenfelvételi technika segítségével. Állattani Közlemények 49(1-4): 113-118.

SzÉKY, P. (1963): A Putorius putorius L. és Putorius furo L. összehasonlító növekedésvizsgálata csontvázméretek alapján. Állattani Közlemények 50(1-4): 151-166.

SzÉKY, P. (1965): Ritka metaplázia egy fiatal nyércben. Magyar Állatorvosok Lapja 3: 132.

SzÉKY, P. (1966): Craniometriás vizsgálatok a vörösróka (Vulpes vulpes L.) koponyáján. Állattani Közlemények 53(1-4): 145-155, +1 tábla.

SzÉKY, P. (1966): Összehasonlító ponty-növekedés-vizsgálati módszer gyakorlati használhatóságának értékelése. Agrártudományi Egyetem Közleményei 23-32.

SzÉKY, P. (1966): Poznatky o rozmnozovani tchora stepneho (Putorius eversmanni Less.) Zbornik Vychodoslovenskaho Muzea VII. B.: 207.

SzÉKY, P. (1967): Allometriai vizsgálatok ragadozó emlősök koponyáján. Állattani Közlemények 54(1-4): 165-172, +1 tábla.

SzÉKY, P. (1969): Testarányok ontogenetikus változásának összehasonlító vizsgálata menyétféléken. Agrártudományi Egyetem Közleményei 47-72.

SzÉKY, P. (1969): Újabb módszer kisemlősök agykoponya kapacitásának meghatározásához. Állattani Közlemények 56(1-4): 147-151, +2 tábla.

SZÉKY, P. (1970): Röntgenaufnahmen in der zoologischen Museumarbeit. Natur und Museum 100: 371-372.

SzÉKY, P. (1972): Adatok a Mustelinae-alfajok kérdéséhez. Agrártudományi Egyetem Mezögazdaságtudományi Karának Közleményei 43-55.

SZÉKY, P. (1973): A mezei nyúl habitusának vizsgálata testsúlyméretek alapján. A vadgazdálkodás fejlesztése 7: 19-33.

SzÉKY, P. (1973): Gödöllő és környéke állatvilága. ATE Agrártudományi Egyetem Tudományos Értesitője 54: 49-57.

SzÉKY, P. (1973): Kutatási módszerek nyúlpopulációk vizsgálatára. A Vadgazdálkodás Fejlesztése 6: $5-23$.

SzÉKY, P. (1973): Variabilitás és allometriás vizsgálatok hazai Mustelida-fajok koponyáin. Agrártudományi Egyetem Tudományos Értesítöje 50: 3-71.

SzÉKY, P. (1974): Adatok a mezei görény (Putorius eversmanni hungarica Éhik) biológiájához. Agrártudományi Egyetem Közleményei 45-61.

SzÉKY, P. (1977): Az etológia szerepe a zoológiai kutatásokban. Allattani Közlemények 64(1-4): 159164.

SZÉKY, P. \& LENNER, L. (1973): Szaporodásbiológiai vizsgálatok a mezeinyúl (Lepus europaeus Pallas) hímjeinél. A Vadgazdálkodás Fejlesztése 7: 19-33. 


\section{Könyvek, könyvrészletek, tudományos kiadványok}

FELFÖldy, L., GÖNCZY, J., PInTÉR, K., SzÉKy, P. \& TASNÁDI, R. (1996): Halgazdálkodás I. Elméleti alapok. Mohosz, Budapest, 203 pp.

NAGY, E. \& SzÉKY, P. (1995): Vadászható és védett vadfajainkról. Nimród alapítvány, Budapest, 224 pp.

SZÉKY P. (1986): A ragadozó és zsákmánya közötti kölcsönhatások ökológiája. In: CsABA, GY. (szerk.): A biológia aktuális problémái. 35. Medicina, Budapest, pp. 203-272.

SzÉKY, P. (1958): 80 címszó a Mezögazdasági Lexikonban. Mezőgazdasági Kiadó.

SzÉKY, P. (1967): A halak élete. Mezőgazdasági Kiadó, Budapest, 111 pp.

SZÉKY, P. (1969): Allometric investigation on growth of some species of Cyprinidae. In: FÁBIÁN, GY. (ed.): Phaenoanalysis and Quantitative Inheritance. Akadémiai Kiadó, Budapest, pp. 176-198.

SzÉKY, P. (1969): Comparative growth study on Putorius putorius L. and Putorius furo L. on the basis of their skeleton measurements. In: FÁBIÁN, Gy. (ed.): Phaenoanalysis and Quantitative Inheritance. Akadémiai Kiadó, Budapest, pp. 49-71.

SzÉKY, P. (1974): Az állatok viselkedésének vizsgálatai I. Az etológia. Az állatok szexuális viselkedése. In: CsABA, Gy. (szerk.): A biológia aktuális problémái. 2. Medicina, Budapest, pp. 154238.

SzÉKY, P. (1975): Az állatok viselkedésének vizsgálata II. Az állatok társas viselkedése. In: CSABA, GY. (szerk.): A biológia aktuális problémái. 3. Medicina, Budapest, pp. 173-241.

SZÉKY, P. (1977): Korunk környezetbiológiája. Tankönyvkiadó, Budapest, 148 pp.

SzÉKY, P. (1977): Térbeli orientáció az állatvilágban. In: CSABA, GY. (szerk.): A biológia aktuális problémái. 10. Medicina, Budapest, pp. 111-166.

SzÉKY, P. (1977): Természetes állatpopulációk ökológiája. In: CSABA, GY. (szerk.): A biológia aktuális problémái. 9. Medicina, Budapest, pp. 133-201.

SzÉKY, P. (1978): A parazita életmód ökológiája. In: CsABA, Gy. (szerk.): A biológia aktuális problémái. 14. Medicina, Budapest, pp. 139-205.

SzÉKY, P. (1978): Térbeli orientáció a gerinctelen állatoknál. In: CSABA, GY. (szerk.): A biológia aktuális problémái. 12. Medicina, Budapest, pp. 63-144.

SZÉKY, P. (1979): A gerinces állatok térbeli orientációja. In: CsABA, GY. (szerk.): A biológia aktuális problémái. 17. Medicina, Budapest, pp. 133-231.

SZÉKY, P. (1979): Etológia. Natura, Budapest, 216 pp.

SzÉKY, P. (1979): Ökológia. A természet erői a mezögazdaság szolgálatában. Natura, Budapest, 174 pp.

SzÉKY, P. (1982): Az állatok közremüködése a virágok megporzásában (zoidiogámia). In: CSABA, GY. (szerk.): A biológia aktuális problémái. 24. Medicina, Budapest, pp. 145-245.

SzÉKY, P. (1983): Nagyság, testarányok és teljesítmény az állatvilágban. In: CsABA, Gy. (szerk.): $A$ biológia aktuális problémái. 28. Medicina, Budapest, pp. 137-208.

SzÉKY, P. (1983): Nyugalmi időszak, pihenés és alvás az élővilágban. In: CsABA, GY. (szerk.): A biológia aktuális problémái. 29. Medicina, Budapest, pp. 137-211.

SZÉKY, P. (1983): Ökológiai kislexikon. Mg. Kiadó, Natura, Budapest, 177 pp.

SzÉKY, P. (1985): Növekedés és formaváltozás. In: CSABA, GY. (szerk.): A biológia aktuális problémái. 32. Medicina, Budapest, pp. 69-150.

SZÉKY, P. (1986): Állat az állatnak üzen. Biokommunikáció. Natura, Budapest, 235 pp.

SzÉKY, P. (1987): Korunk környezetbiológiája. Második, bővített kiadás. Tankönyvkiadó, Budapest, $153 \mathrm{pp}$. 
SzÉKY, P. (1989): A Föld állatvilága. Kis állatföldrajz. Mezőgazdasági Kiadó, Budapest, 184 pp.

SzÉKY, P. (1995): Zoológiai értelmezö szótár. Mezőgazda Kiadó, Budapest, 376 pp.

\section{Tankönyvek, egyetemi jegyzetek és oktatási anyagok ${ }^{1}$}

BAKonyi, G., KisS, I., S. HLubiK, I. \& SzÉKy, P. (szerk. S. HlubIK, I.) (1982): Állattani gyakorlatok II. (egyetemi jegyzet), Agrártudományi Egyetem, Gödöllö, 183 pp.

FÁbiÁn, Gy., MolnÁr, Gy., NAGy, E. \& SzÉKy, P. (1975): Biológia II. Jegyzet egyetemi és főiskolai előkészítő tanfolyam hallgatói számára. Agrártudományi Egyetem, Gödöllő, pp. 59-145.

KÖlÜS, G., MolnÁR, Gy., NAGY, E. \& SzÉKy, P. (1956): Rendszeres állattan. (tankönyvpótló jegyzet), Agrártudományi Egyetem, Agronómiai és Állattenyésztési Kar, 415 pp.

Sinkovitsné HLUBIK, I. \& SzÉKY, P. (1970): Határozókulcs a fontosabb rovarrendek meghatározásához. (egyetemi jegyzet), Agrártudományi Egyetem, Gödöllő, 20 pp.

SzÉKY, P. \& BAKONYI, G. (1975): Gerincesek, Az állatok életfolyamatai, Az állat és környezete. pp. 59-145. In: HortobÁGYI, T. (szerk.): Biológia II. (jegyzet a Szakmunkások Egyetemi Főiskolai Előkészítő tanfolyama számára), Agrártudományi Egyetem, Gödöllő, 154 pp.

SzÉKY, P. (1956): Gazdasági állattan. (tankönyv mezőgazdasági technikumi tanulók számára), Mezőgazdasági Kiadó, Budapest, 258 pp.

SzÉKY, P. (1961): Puhatestűek (Mollusca), Halak (Pisces), Kétéltüek (Amphibia), Hüllők (Reptilia) pp. 271-327, Emlösök (Mammalia) pp. 395-460, Rövid áttekintés az állati test szerveiről összehasonlító anatómiai szemszögböl pp. 461-478. In: FÁBIÁN, GY. (szerk.): Állattan. (tankönyvpótló egyetemi jegyzet), Agrártudományi Egyetem, Mezőgazdaságtudományi Kar, Gödöllő, 514 pp.

SzÉKY, P. (1961): Útmutató az Állattan c. tárgyhoz (levelező hallgatók részére). Agrártudományi Egyetem, Gödöllö, 12 pp.

SzÉKY, P. (1962): Halanatómia és halélettan. (szakmérnökképzés jegyzete Halgazdasági szak hallgatói számára), Agrártudományi Egyetem, Mezőgazdaságtudományi Kar, Gödöllő, 118 pp.

SzÉKY, P. (1965): Puhatestűek. pp. 183-187., Fejgerinchúrosok, halak, kétéltüek, hüllök. pp. 297347., Rövid áttekintés az állati test szerveiről, összehasonlító anatómiai szemszögből. pp 460490. In.: FÁBIÁN Gy. (szerk): Állattan mezögazdasági mérnökök részére. Mezőgazdasági Kiadó, Budapest, $551 \mathrm{pp}$.

SZÉKY, P. (1973): Puhatestűek. pp. 207-214., Magzatburok nélküliek, halak, kétéltűek, hüllők. pp. 330-373., Rövid áttekintés az állati test szerveiről, összehasonlító anatómiai szemszögből. pp 503-533. In.: FÁBIÁN GY. (szerk.): Állattan mezögazdasági mérnökök részére. Második átdolgozott, bővített kiadás. Mezőgazdasági Kiadó, Budapest, 587 pp.

SzÉKY, P. (1974): A környezetvédelem zoológiai alapjai. (szöveganyag) pp. 28-35. In: Környezetvédelmi oktatási irányelvek a MÉM Felsőoktatási Intézmények számára. Agrártudományi Egyetem, Gödöllö, I. köt. 261 pp.

SzÉKY, P. (1974): A környezetvédelem zoológiai alapjai. pp. 28-35. (+ ábraanyag, pp. 1-36.) In: Környezetvédelmi oktatási irányelvek a MÉM Felsőoktatási Intézmények számára. Agrártudományi Egyetem, Gödöllö, III. köt. 36 pp.

SZÉKY, P. (1975): Demökológia. pp. 115-189. In: FÁBIÁN, GY. (szerk.): Ökológia. (jegyzet környezetvédelmi szakmérnökök részére), Agrártudományi Egyetem, Gödöllő, 245 pp.

SzÉKY, P. (1977): Puhatestüek pp. 214-219., Magzatburok nélküliek, halak, kétéltüek, hüllők. pp. 339-383., Rövid áttekintés az állati test szerveiről, összehasonlító anatómiai szemszögből. pp 488-518. In.: FÁBIÁN GY. (szerk.): Állattan mezögazdasági mérnökök részére. Harmadik bővített kiadás. Mezőgazdasági Kiadó, Budapest, 615 pp. 
SzÉKY, P. (1978): Az állatok szerepe az ökológiai rendszerben. Az ember rendszert szabályozó szerepe. pp. 1-22. In: ENDRÖDI P. (szerk.): Környezetvédelem. I. köt. (segédlet előadók részére), Tudományos Ismeretterjesztő Társulat, Budapest. Központi Kiadvány, 508 pp.

SzÉKY, P. (1979): Az emlősök származástana és rendszerezése, A nálunk élő vadászható, illetve ragadozó emlősök rendszertani besorolása. pp. 7-8., Az emlősök növekedése és fejlődése, életszakaszok, életkor. pp. 115-130., Párosujjú patások (Artiodactyla) rendje. pp. 139-146., Kérődzők (Ruminantia) alrendje. pp. 166-168., Nyúlalakúak (Lagomorpha) rendje. pp. 253-254., Ragadozó emlősök (Carnivora) rendje. pp 294-335. In: SzÉKY, P. (szerk.): Vadászati állattan II. (Emlösök). Egyetemi jegyzet Vadgazdálkodási Szakmérnökök részére, Agrártudományi Egyetem, Gödöllö, $342 \mathrm{pp}$.

SzÉKY, P. (1982): Halélettan. (mezőgazdasági szakmunkásképzés tankönyve), Mezőgazdasági Kiadó, $225 \mathrm{pp}$.

SZÉKY, P. (1989): Emlősök (Mammalia). pp. 127-190. In: NAGY, E. (szerk.): Vadászati állattan. (tananyag a vadász- vadtenyésztő szakmát oktató szakközépiskolák számára), MÉM Szakoktatási és Kutatási Főosztálya, Budapest. Agrárszakoktatási Intézet, Gödöllő, 198 pp.

SzÉKY, P. (1989): Ökológia I. (egyetemi jegyzet vadgazdálkodási szakmérnök-hallgatók részére), Agrártudományi Egyetem, Mezőgazdaságtudományi Kar, Állattani és Vadbiológiai Intézet, Gödöllő, $230 \mathrm{pp}$.

\section{Ismeretterjesztö cikkek}

SzÉKY, P. (1955): Halljunk a vízisiklóról. Halászat 2(9): 169.

SzÉKY, P. (1955): Hozzászólás a haljelölés kérdéséhez. Halászat 2(7): 137.

SZÉKY, P. (1956): Ismerkedjünk meg a halak anyagcseréjével. Halászat 3(2): 30-31.

SzÉKY, P. (1956): Ismerkedjünk meg a halak anyagcseréjével. Halászat 3(1): 6.

SZÉKY, P. (1956): Ismerkedjünk meg a halak anyagcseréjével. Halászat 3(3): 50-51.

SzÉKY, P. (1956): Mit tudunk a halvérről? Halászat 3(4): 64.

SZÉKY, P. (1956): Mit tudunk a tegzesekről? Halászat 3(9): 164.

SzÉKY, P. (1958): Hogyan ízlelnek és szagolnak a halak? Halászat 5(12): 229.

SzÉKY, P. (1958): Mit ér a halhús? Halászat 5(4): 70-71.

SzÉKY, P. (1958): Mit tudunk a halak úszóhólyagjáról? Halászat 5(2): 25.

SzÉKY, P. (1959): A rovarvilág legszebb "repülőgépei" a szitakötők. Halászat 6(5): 86-87.

SzÉKY, P. (1959): Hogyan látnak a halak? Halászat 6(1): 7.

SzÉKY, P. (1959): Ismerjük meg csigáinkat is! Halászat 6(3): 47.

SZÉKY, P. (1959): Ismerjük meg kagylóinkat. Halászat 6(2): 30-31.

SzÉKY, P. (1959): Vitatkozzunk. Halászat 6(2): 32.

SzÉKY, P. (1960): Halcsont, halszálka. Halászat 7(5): 85.

SZÉKY, P. (1960): Miért "éberek" a halak? Halászat 7(1): 5.

SzÉKY, P. (1960): Mit tudunk a halak bőréröl? Halászat 7(4): 65.

SzÉKY, P. (1962): Halaink fejlődése és növekedése I. Halászat 8(55)3: 60-61.

SzÉKY, P. (1962): Halaink fejlődése és növekedése II. Halászat 8(55)4: 95.

SZÉKY, P. (1962): Halaink fejlődése és növekedése III. (Ivadék életszakasz). Halászat 8(55)5: 135.

SZÉKY, P. (1962): Halaink fejlődése és növekedése IV. Halászat 8(55)6: 146.

SZÉKY, P. (1962): Halaink fejlődése és növekedése V. Halászat 8(55)3: 60-61. 
SZÉKY, P. (1963): A halnak is van pajzsmirigye? Halászat 9(56)3: 79.

SZÉKY, P. (1963): A halnövekedés vizsgálatának módszereiről. Halászat 9(56)1: 8.

SzÉKY, P. (1963): Halak és hormonok. Halászat 9(56)2: 38.

SzÉKY, P. (1963): Mit csinálnak halaink télen? Halászat 9(56)6: 192.

SzÉKY, P. (1963): Mit tudunk a halak mellékveséjéről és hasnyálmirigyéről? Halászat 9(56)5: 135.

SZÉKY, P. (1964): A dinamikus morfológia szerepe a zoológiában. Természettudományi Közlöny 8(95)11: 493-497.

SZÉKY, P. (1964): A hal és a fénysugár. Halászat 10(57)5: 142.

SzÉKY, P. (1964): A hal és környezete. Halászat 10(57)4: 97.

SzÉKY, P. (1964): A halak színe és színének változásai. Halászat 10(57)6: 174.

SzÉKY, P. (1964): Az állatok színeződésének titkai. Természettudományi Közlöny 8(95)2: 59-61.

SzÉKY, P. (1964): Hogyan találja meg a hal ondósejtje az ikrát? Halászat 10(57)2: 45.

SZÉKY, P. (1964): Hozzászólás a szakemberképzés kérdéséhez. Halászat 10(57)4: 126.

SzÉKY, P. (1964): Még valamit a kínai halakról! Halászat 10(57)1: 9.

SZÉKY, P. (1964): Miért pipál a hal? Halászat 10(57)3: 86.

SzÉKY, P. (1964): Újabb vizsgálati eredmények a halak oldalvonaláról. Halászat 10(57)6: 186-187.

SzÉKY, P. (1965): A hal mozgásáról. Halászat 11(58)5: 133.

SzÉKY, P. (1965): A halak hidrosztatikája: Az úszóhólyag szerepe a halak életében. Természettudományi Közlöny 9(96)4: 162-167.

SzÉKY, P. (1965): A halak ivarsejtjeinek kifejlődése. Halászat 11(58)2: 46.

SzÉKY, P. (1965): A szaglás biológiája. Természettudományi Közlöny 9(96)8: 343-347.

SZÉKY, P. (1965): Halaink életmódja. Halászat 11(58)1: 34.

SZÉKY, P. (1965): Hasznos tudnivalók a harcsáról. Halászat 11(58)1: 11.

SzÉKY, P. (1965): Isznak-e a halak? Halászat 11(58)3: 72.

SZÉKY, P. (1965): Izotópok sorsa a hal szervezetében. Halászat 11(58)6: 173.

SzÉKY, P. (1965): Miért mozog a hal kopoltyúfedője? Halászat 11(58)4: 118.

SzÉKY, P. (1966): A halak hormontermelő mirigyei. Búvár 11(6): 342-347.

SzÉKY, P. (1966): A vadmacska. Természettudományi Közlöny 10(3): 125-126. ${ }^{1}$

SzÉKY, P. (1966): Élő generátorok: Elektromosáram-termelés az állati szervezetben. Természettudományi Közlöny 10(97)11: 488-491.

SzÉKY, P. (1966): Hogyan egyensúlyozza testét a hal? Halászat 12(59)1: 8.

SzÉKY, P. (1966): Mit tudunk a halak fogairól? Halászat 12(59)3: 93.

SzÉKY, P. (1966): Világító állatok. Természettudományi Közlöny 10(97)4: 154-159.

SzÉKY, P. (1967): Hanglokáció az állatvilágban. Természettudományi Közlöny 11(98)2: 56-60.

SZÉKY, P. (1967): Szagolnak-e a madarak? Természettudományi Közlöny 11(98)11: 509-512.

SzÉKY, P. (1967): Vigyázat, nagyfeszültség! (I). Természettudományi Közlöny 11(98)6: 262, 266267.

SzÉKY, P. (1967): Vigyázat, nagyfeszültség! (II). Természettudományi Közlöny 11(98)7: 308-310.

SzÉKY, P. (1968): A hal és a vízhőmérséklet. Halászat 14(61)4: 100-101.

\footnotetext{
${ }^{1}$ Tévesen Hudetz József nevén jelent meg, aki a fotókat készítette a cikkhez.
} 
SzÉKY, P. (1968): A halikra startja. Halászat 14(61)2: 43.

SzÉKY, P. (1968): Az állatok hőmérője. Természet világa: Természettudományi Közlöny 12(99)6: 259-262.

SZÉKY, P. (1969): A halak bajuszáról. Halászat 15(62.)5: 136-137.

SzÉKY, P. (1969): A nyomkövető rovarok. Természet világa: Természettudományi Közlöny 13(100)5: 198-202, 212.

SzÉKY, P. (1969): Ismert, mégis "ismeretlen" állat: a görény. Természet világa: Természettudományi Közlöny 13(100)11: 510-513.

SzÉKY, P. (1970): A gerinctelenek „,bölcsőjé”-nél: fajfenntartás az állatvilágban). Természet világa: Természettudományi Közlöny 14(101)8: 361-364.

SzÉKY, P. (1970): A szaporodás és az etológia: Gerinces állatok "szerelmi" élete. Természet világa: Természettudományi Közlöny 14(101)10: 454-458.

SzÉKY, P. (1971): A higany, az állat és az ember. Természet világa: Természettudományi Közlöny 15(102)6: 248-249.

SzÉKY, P. (1971): Természetes vízi halaink tanulékonysága. Halászat 17(64)4: 122-123.

SzÉKY, P. (1972): A vadnyulak nyomában. Természet világa: Természettudományi Közlöny 103(4): $155-158,179$.

SzÉKY, P. (1972): Az állatok "termosztátja": Hőszabályozás az állatvilágban. Természet világa: Természettudományi Közlöny 103(10): 434-438.

SzÉKY, P. (1973): A hal a csalit észreveszi. Magyar Horgász 27(4): 56-57.

SzÉKY, P. (1973): A halak élete. Magyar Horgász 27(3): 45.

SzÉKY, P. (1973): A mezei nyúl életkorának meghatározása. Nimród 5(6): 6.

SzÉKY, P. (1973): A rovarok fejlődésének titkai: A metamorfózis mozgató rugói. Természet világa: Természettudományi Közlöny 104(5): 223-227.

SzÉKY, P. (1973): Biogeokémiai folyamatok. Az elemek körforgása. Természet világa: Természettudományi Közlöny 104(8): 365-367.

SzÉKY, P. (1973): Hogyan mozog a hal? Magyar Horgász 27(6): 88-89.

SzÉKY, P. (1973): Hogyan táplálkozik a hal? Magyar Horgász 27(7): 106-108.

SZÉKY, P. (1973): Légzés és vérkeringés. Magyar Horgász 27(8): 116-117.

SzÉKY, P. (1973): Miért olyan éberek a halak? Magyar Horgász 27(5): 70-71.

SZÉKY, P. (1973): Szőrmés ragadozóinkról. Nimród 5(7): 14-15.

SzÉKY, P. (1974): "Melegvérü" halak. Természet világa: Természettudományi Közlöny 105(1): 36-38.

SzÉKY, P. (1974): A halak is szomjaznak. Magyar Horgász 28(7): 109.

SzÉKY, P. (1974): A ragadozó és zsákmánya. Természet világa: Természettudományi Közlöny 105(12): 553-557.

SZÉKY, P. (1974): Mit hall a ponty a víz alatt? Halászat 20(67)4: 118-119.

SzÉKY, P. (1974): Orvosi és élettani Nobel-díjasok. Természet világa: Természettudományi Közlöny 105(2): 57-58.

SZÉKY, P. (1974): Prémes ragadozók a vízparton. Halászat 20(67)2: 52.

SzÉKY, P. (1974): Riadó a halak életében. pp. 96-99. In: VíGH, J. (szerk.): Horgász Évkönyv 1975. $156 \mathrm{pp}$.

SzÉKY, P. (1974): Színlátás az élők világában. Természet világa: Természettudományi Közlöny 105(8): 358-362, 368. 
SzÉKY, P. (1975): A sejtmozgás bonyodalmai: Újabb adatok a csillók és ostorosok mozgásáról. Természet világa: Természettudományi Közlöny 106(8): 346-351.

SzÉKY, P. (1975): A vörösvértestek élete. Természet világa: Természettudományi Közlöny 106(2): 7071.

SzÉKY, P. (1975): Bemutatjuk az Agrokémiai és Talajtani Intézetet. Természet világa 106(9): 422425.p.

SzÉKY, P. (1975): Csend van-e a víz tükre alatt? pp. 55-60. In: ViGH, J. (szerk.): Horgász Évkönyv 1975. $156 \mathrm{pp}$.

SzÉKY, P. (1975): Meddig elég a légkör oxigénje? Természet világa 106(12): 569-570.

SzÉKY, P. (1975): Mitől függ a hal "jó közérzete"? Halászat 21(68)2: 46-48.

SzÉKY, P. (1975): Védett emlőseink: a borz és a vidra. Búvár 30(6): 262-266.

SzÉKY, P. (1976): Etológia: magatartás az életközösségben. Élet és Tudomány 31(21): 963-969.

SzÉKY, P. (1976): Ökológia '75: Konkurrencia az életközösségben: Pályázatunk II. díjjal jutalmazott cikke. Búvár 31(1): 7-12.

SzÉKY, P. (1976): Van-e biológiai egyensúly? Az ökológiai rendszerek szabályozása. Természet világa: Természettudományi Közlöny 107(6): 245-249.

SzÉKY, P. (1977): A repülés evolúciója. Természet világa: Természettudományi Közlöny 108(1): 9$13,44$.

SzÉKY, P. (1977): Az ivadékgondozás etológiája. Természet világa: Természettudományi Közlöny 108(11): 520-523.

SZÉKY, P. (1977): Gödöllő és közvetlen környékének állatvilága. Gödöllő és vidéke helytörténeti füzetek 1: 51-60.

SzÉKY, P. (1977): Ismét van európai bölény. Természet világa: Természettudományi Közlöny 108(10): 436.

SZÉKY, P. (1977): Kevéssé ismert védett gerincesünk: A vadmacska: Téves ítéletek - és tények. Búvár 32(3): 122-126.

SzÉKY, P. (1977): Melyik nem volt előbb? Természet világa: Természettudományi Közlöny 108(6): 266-268.

SzÉKY, P. (1977): Nőstények számszerủ túlsúlya egy erdei lemming-populációban. Természet világa: Természettudományi Közlöny 108(10): 436.

SZÉKY, P. (1977): Rendszer a természetben. Köznevelés 33(8): 13-14.

SzÉKY, P. (1977): Tavaink romlása és egy kagylófaj élete I. Magyar Horgász 29(1): 12-13.

SzÉKY, P. (1977): Tavaink romlása és egy kagylófaj élete II. Magyar Horgász 29(2): 56-57.

SzÉKY, P. (1977): Védett fajok - az 1975. évi vadászati kimutatásban. Búvár 32(1): 42.

SzÉKY, P. (1978): A C-vitamin a természet egyik tévedése? Természet világa: Természettudományi Közlöny 109(5): 226-227.

SzÉKY, P. (1978): A fehérje szerepe és sorsa a szervezetben (Plósz PÁL). Természet világa: Természettudományi Közlöny 109(3): 113.

SzÉKY, P. (1978): A lihegés biológiája. Természet világa: Természettudományi Közlöny 109(8): 354355.

SzÉKY, P. (1978): Állatökológia. Társas kapcsolatok az állatvilágban: Az élősködéstől az együttélésig. Búvár 33(3): 118-123.

SZÉKY, P. (1978): Az élősködő életmód ökológiája. Köznevelés 26. évf. pp. 13-14.

SzÉKY, P. (1978): Az ökológiai gondolkozásmód elterjesztéséért. Búvár 33(2): 88. 
SzÉKY, P. (1978): Messziről jött különös halfajunk az angolna. pp 108-113. In: VIGH, J. (szerk.): Horgászkalauz1979. 156 pp.

SzÉKY, P. (1978): Nagyság és növekedés az állatvilágban. Természet világa: Természettudományi Közlöny 109(12): 538-541.

SzÉKY, P. (1978): Ökológia: Táplálkozási kapcsolatok az életközösségekben. Búvár 33(9): 402-407.

SzÉKY, P. (1979): Ökológia: A hőmérséklet, mint környezeti tényező: Fokozottabb figyelmet érdemel. Búvár 34(10): 450-454.

SzÉKY, P. (1979): Testnagyság és testfelület. Természet világa: Természettudományi Közlöny 110(1): $5-7$.

SzÉKY, P. (1980): A környezet - és a növények szaporodása. Természet világa: Természettudományi Közlöny 111(10): 456-459.

SzÉKY, P. (1980): A szaglóképesség egyik csúcspontja az állatvilágban. Természet világa: Természettudományi Közlöny 111(11): 495.

SzÉKY, P. (1980): Az élőlények csoportosításának újabb felfogása. Természet világa: Természettudományi Közlöny 111(9): 400.

SZÉKY, P. (1980): Etológia. Halászat 26(73)2: 63.

SZÉKY, P. (1980): Kölcsönkapcsolatok növények és állatok között: Hogyan viszonozza az állat a növény szolgáltatásait? Természet világa: Természettudományi Közlöny 111(7): 307-311.

SzÉKY, P. (1980): Természeti környezetünk és a korszerű mezőgazdaság: Egy természetes és egy ember által irányított ökoszisztéma összehasonlítása. Természet világa: Természettudományi Közlöny 111(1): 18-23.

SzÉKY, P. (1981): Az élölények és a légköri oxigén. Természet világa: Természettudományi Közlöny 112(12): 546-549.

SzÉKY, P. (1981): Mellőzött állataink: a folyami rákok. Természet világa: Természettudományi Közlöny 112(4): 178-180.

SzÉKY, P. (1982): A koplalás bajnokai, a skorpiók. Élet és Tudomány 43: 1359-1361.

SzÉKY, P. (1982): A légzés evolúciója. Természet világa: Természettudományi Közlöny 113(1): 2328.

SzÉKY, P. (1982): A természet háztartása. Búvár 37(8): 347-350.

SZÉKY, P. (1982): Talajökológia: Pótolhatatlan talajélet. Búvár 37(2): 62-65.

SzÉKY, P. (1983): A gerinces állatok hallása és hangadása. Természet világa: Természettudományi Közlöny 114(12): 536-540.

SzÉKY, P. (1983): A populációk ökológiája. Természet világa: Természettudományi Közlöny 114(6): 262-266.

SzÉKY, P. (1983): Az elektromos jelek szerepe a halak életében. Természet világa: Természettudományi Közlöny 114(8): 348-352.

SzÉKY, P. (1983): Halélettan. Halászat 29(76)1: 28.

SZÉKY, P. (1983): Horgászoknak: ismerjük-e a csukát? pp. 37-40. In: VIGH, J.(szerk.): Horgászkalauz 1984. $160 \mathrm{pp}$.

SzÉKY, P. (1984): A kakukk és a költésparazitizmus. Természet világa: Természettudományi Közlöny 115(6): 256-259.

SZÉKY, P. (1984): A rivókaféreg. Természet világa: Természettudományi Közlöny 115(4): 175-177.

SzÉKY, P. (1985): A természetet segítve: Változó populáció. Búvár 40(4) 173-175. 
SzÉKY, P. (1985): A vizek sótartalma és az élővilág. Természet világa: Természettudományi Közlöny 116(3): 126-128.

SzÉKY, P. (1985): Különös kapcsolat két állatfaj között. Természet világa: Természettudományi Közlöny 116(8): 378-380.

SzÉKY, P. (1985): Megmenekül a címermadár? Természet világa: Természettudományi Közlöny 116(2): 72.

SzÉKY, P. (1985): Oktalan ellenszenv. Természet világa: Természettudományi Közlöny 116(1): 32.

SzÉKY, P. (1986): "Kakukk-módszer" az ormányosbogaraknál. Természet világa: Természettudományi Közlöny 117(4): 178-181.

SzÉKY, P. (1986): A balin biológiája pp. 29-30. In: VIGH, J.(szerk.): Horgászkalauz 1987. 160 pp.

SzÉKY, P. (1986): A növények kémiai önvédelme. Természet világa: Természettudományi Közlöny 117(6): 255-259.

SzÉKY, P. (1986): Álmodnak-e a macskák? Természet világa: Természettudományi Közlöny 117(12): 557.

SzÉKY, P. (1987): A könnyezés élettana és evolúciója. Természet világa: Természettudományi Közlöny 118(6): 200-203.

SZÉKY, P. (1987): Élet az örök sötétség birodalmában: A barlang élővilága és ökológiája. Természet világa: Természettudományi Közlöny 118(10): 386-390.

SzÉKY, P. (1987): Kémiai védekezésmódok az állatvilágban. Természet világa: Természettudományi Közlöny 118(1): 12-17.

SzÉKY, P. (1988): A gerinces állat harmadik szeme - a tobozmirigy. Természet világa: Természettudományi Közlöny 119(11): 496-499.

SzÉKY, P. (1988): Az afrikai hiénakutyák jobbak, mint a hírük. Természet világa: Természettudományi Közlöny 119(8): 369.

SzÉKY, P. (1988): Ivari konfliktus az állatvilágban. Természet világa: Természettudományi Közlöny 119(9): 392-397.

SzÉKY, P. (1988): Mit tudunk s mit nem a "közönséges" sünről? Természet világa: Természettudományi Közlöny 119(3): 132-134.

SzÉKY, P. (1988): Tigris a hóban? Természet világa: Természettudományi Közlöny 119(7): 317.

SzÉKY, P. (1989): A havasi mormota. Természet világa: Természettudományi Közlöny 120(5): 229_ 231.

SzÉKY, P. (1989): A természet trágyahordói. Élet és tudomány 44(41): 1298-1300.

SzÉKY, P. (1989): Alapfogalmak és módszerek: Ökológiáról mindenkinek. Búvár 44(12): 30-31.

SZÉKY, P. (1989): Egy kis történelem. Búvár 44(11): 18-19.

SZÉKY, P. (1989): Elemek - körforgalomban. pp. 246-251. In: SZUHAI-HAVAS ERVIN (szerk.): Az Élet és tudomány Kalendáriuma 1990. Hírlapkiadó Vállalat, Budapest 384 pp.

SZÉKY, P. (1989): Élet az utak mentén. Élet és tudomány 44(36): 1133-1135.

SzÉKY, P. (1989): Ezerszínü állatvilág. Búvár 44(9): 15-17.

SZÉKY, P. (1989): Gyantába zárt évmilliók. Búvár 44(9): 22-23.

SZÉKY, P. (1989): Viták és érdekességek egy betelepített halfajról. Természet világa: Természettudományi Közlöny 120(11): 528-531.

SzÉKY, P. (1990): "Haszonleső" állatok. Természet világa: Természettudományi Közlöny 121(2): 6266.

SZÉKY, P. (1990): A "vörös hadsereg" kivonulása. Élet és tudomány 45(22): 690-692. 
SzÉKY, P. (1990): A hangya-"állam" megalapozása és szerveződése. Természet világa: Természettudományi Közlöny 121(8): 360-363.

SzÉKY, P. (1990): A hangyák a "szorgalom" mintaképei. Természet világa: Természettudományi Közlöny 121(7): 322-325.

SzÉKY, P. (1990): Az elefántagyar és fogazat története. A Természet 41(9-10): 175-177.

SzÉKY, P. (1990): Egy különös csontképlet a halak testében: a garatcsont. A Természet 41(9-10): 166-168.

SzÉKY, P. (1990): Élet a kőfalak repedéseiben. TermészetBúvár 45(3): 36-37.

SzÉKY, P. (1990): Élet a patakokban, folyókban. TermészetBúvár 45(1): 16-19.

SzÉKY, P. (1990): Macskák a vadonban. I. rész. A Természet 41(Próbaszám): 11-17.

SzÉKY, P. (1990): Macskák a vadonban. II. rész. A Természet 41(2): 26-31.

SzÉKY, P. (1990): Macskák a vadonban. III. rész. A Természet 41(3): 49-54.

SzÉKY, P. (1990): Macskák a vadonban. IV. rész. A Természet 41(4): 71-75.

SzÉKY, P. (1990): Macskák a vadonban. V. rész. A Természet 41(5): 90-92.

SZÉKY, P. (1990): Macskák a vadonban. VI. rész. Nagytestü "kismacskák" és az igazi nagymacskák. $A$ Természet 41(6): 107-112.

SzÉKY, P. (1990): Szarv és agancs - zoológus szemmel. Természet világa: Természettudományi Közlöny 121(9): 392-398.

SzÉKY, P. (1990): Szőrős hernyó - címfotót magyarázó szöveg. Természet világa: Természettudományi Közlöny 121(5): 203.

SzÉKY, P. (1991): A foraminiferák különös hőérzékenysége. Természet világa: Természettudományi Közlöny 122(8): 377-378.

SzÉKY, P. (1991): A gyógyító és mérgező higany. TermészetBúvár 46(1): 14-15.

SzÉKY, P. (1991): A hernyó "hallószerve". Természet világa: Természettudományi Közlöny 122(9): 420-421.

SzÉKY, P. (1991): Furcsaságok - rendellenességek. A Természet 42(3): 49-51.

SzÉKY, P. (1991): Hogyan szövi hálóját a pók? Természet világa: Természettudományi Közlöny 122(10): 445-450.

SzÉKY, P. (1991): Koevolúciós versenyfutás. Természet világa: Természettudományi Közlöny 122(4): 152-157.

SzÉKY, P. (1991): Különös bogárfajok a nyári éjszakában. A Természet 42(6): 102-104.

SzÉKY, P. (1991): Pödörnyelv. Természet világa: Természettudományi Közlöny 122(4): 189.

SzÉKY, P. (1992): A faunahamisítás veszélyei. TermészetBúvár 47(2): 18-19.

SzÉKY, P. (1992): A párválasztás nehézségei az állatvilágban. Természet világa: Természettudományi Közlöny 123(6): 264-267.

SZÉKY, P. (1992): A Természet bonyolult rendszere. Magyar Vadászlap 1(12): 8.

SZÉKY, P. (1992): Az igazgyöngy. Természet világa: Természettudományi Közlöny 123(9): 422-423.

SzÉKY, P. (1992): Egy különös belső szerv. A halak úszóhólyagja. A Természet 43(1): 3-7.

SzÉKY, P. (1992): Gyorsuló evolúció. Természet világa: Természettudományi Közlöny 123(5): 230231.

SzÉKY, P. (1992): Ismerkedés az ökológiával I. Magyar Vadászlap 1(11): 8.

SzÉKY, P. (1992): Lepkeszárny a nagyító alatt. Szakszöveg a címfotóhoz. Természet világa: Természettudományi Közlöny 123(3): 127-128. 
KISS I. \& BAKONYI G.

SzÉKY, P. (1993): A halak fejlődéstörténete. Természet világa: Természettudományi Közlöny 124(1): $42-43$.

SzÉKY, P. (1993): A Hold hatása a Föld élővilágára. Természet világa: Természettudományi Közlöny 124(4): $168-171$.

SZÉKY, P. (1993): A honfoglalás feltételei. TermészetBúvár 48(1): 26-27.

SzÉKY, P. (1993): Az élővilág új törzsfája. Természet világa: Természettudományi Közlöny 124(11): 515-517.

SZÉKY, P. (1993): Vadászati ökológia 10. /A vadpopulációk jellemzői/. Magyar Vadászlap 2(8): 8.

SzÉKY, P. (1993): Vadászati ökológia 11. /A populáció szaporodóképessége és mortalitása/. Magyar Vadászlap 2(9): 8.

SzÉKY, P. (1993): Vadászati ökológia 12. /A vadpopuláció létszámváltozása/. Magyar Vadászlap 2(11): 8.

SzÉKY, P. (1993): Vadászati ökológia 3. /A vad élöhelye/. Magyar Vadászlap 2(1): 8.

SzÉKY, P. (1993): Vadászati ökológia 4. /Az apróvad élettere a rét és a legelő, Vízi élőlények/. Magyar Vadászlap 2(2): 8.

SzÉKY, P. (1993): Vadászati ökológia 5. /A vadászterület nemcsak a vadé! Milyen a vad élőhelyének életközössége?/. Magyar Vadászlap 2(3): 8.

SzÉKY, P. (1993): Vadászati ökológia 6. /Táplálékláncokból táplálékhálózat/. Magyar Vadászlap 2(4): 8.

SzÉKY, P. (1993): Vadászati ökológia 7. /Történések az ökológiai rendszerekben/. Magyar Vadászlap 2(5): 8.

SzÉKY, P. (1993): Vadászati ökológia 8. /Milyen egy vadpopuláció?/. Magyar Vadászlap 2(6): 8.

SzÉKY, P. (1993): Vadászati ökológia 9. /Létszám helyett átlagos egyedsürüség/. Magyar Vadászlap 2(7): 8.

SZÉKY, P. (1994): A gerinces állatok metamorfózisa: az átalakulásos egyedfejlődés az állatvilágban. Természet világa: Természettudományi Közlöny 125(6): 260-263.

SZÉKY, P. (1994): A kutyafélék vadon élő képviselöi. A Természet 45(2): 25-28.

SzÉKY, P. (1994): Átalakulásos egyedfejlődés az állatvilágban. Természet világa: Természettudományi Közlöny 125(5): 206-210.

SzÉKY, P. (1994): Az emlősök "ruhája", a ször. Természet világa: Természettudományi Közlöny 125(3): 110-115.

SzÉKY, P. (1994): Vadászati ökológia 14. /A tervszerü vadlétszám-szabályozás ökológiai alapjai/. Magyar Vadászlap 3(1): 8.

SzÉKY, P. (1994): Vadászati ökológia 15. /Befolyásoló tényezők kapcsolatrendszere/. Magyar Vadászlap 3(2): 8.

SzÉKY, P. (1994): Vadászati ökológia 16. /Az állat viselkedésének lényege és megismerésének haszna/. Magyar Vadászlap 3(3): 8.

SzÉKY, P. (1994): Vadászati ökológia 16. /Ökológiai szempontok a vadlétszámbecslés körüli vitához/. Magyar Vadászlap 3(4): 8.

SzÉKY, P. (1994): Vadászati ökológia 17. /Ragadozó és zsákmánya közti viszony/. Magyar Vadászlap 3(5): 8.

SzÉKY, P. (1995): A fogazat evolúciója. Természet világa: Természettudományi Közlöny 126(10): 446-450. 
SzÉKY, P. (1995): Az élőlények nyugalmi állapota: nem csak téli az álom. Természet világa: Természettudományi Közlöny 126(1): 6-9.

SzÉKY, P. (1995): Újabb részletek a virágjáró rovarok szájszervéről. Természet világa: Természettudományi Közlöny 126(5): 223-225.

SzÉKY, P. (1996): A fogazat evolúciója: a ma élő emlősök fogazata. Természet világa: Természettudományi Közlöny 127(2): 69-73.

SzÉKY, P. (1996): Hogyan készül a méz? Természet világa: Természettudományi Közlöny 127(8): 379-380.

SZÉKY, P. (1997): A madárdal ihletője. TermészetBúvár 52(3): 18-19.

SzÉKY, P. (1997): Az Antarktiszt övező tengerek állatvilága. Természet világa: Természettudományi Közlöny 128(4): 187-189.

SzÉKY, P. (1997): Vetélkedés az állatvilágban. Természet világa: Természettudományi Közlöny 128(7): 297-300.

SzÉKY, P. \& NÉMETH, G. (1992): Féregnyomok a homokban. Élet és tudomány 47(30): 959.

\section{Tudományos értekezések}

SZÉKY, P. (1961): A posztembrionális növekedés morfogenézisének vizsgálata fontosabb tógazdasági halainkon. Doktori értekezés. Agrártudományi Egyetem, Gödöllő, 104 pp.

SzÉKY, P. (1970): Variabilitás és allometriás vizsgálatok a hazai Mustelida-fajoknál. Kandidátusi értekezés. Agrártudományi Egyetem, Gödöllö, 282 pp.

\section{Könyvfordítások}

KreBS, J.K., DAvies, N. B.: Bevezetés a viselkedésökológiába. Mezőgazdasági Kiadó, Budapest, 1988

GRzIMEK, B.: Grzimeks Enzyklopädie der Tiere. Säugetiere II. kötetböl: Főemlősök általános jellemzése (pp. 14-29.), Félmajmok (pp. 32-104.).

\section{Könyvismertetések}

Koltay, A. \& SzÉKY, P. (1981): Egy új könyv margójára: Megjegyzések Perendy M.: "Biológiai gyakorlatok kézikönyve" címủ könyvéhez. Természet világa: Természettudományi Közlöny 112(6): 275-277.

SzÉKY, P. (1978): HoldAS, S.: Prémek, szőrmék, prémes állatok. Búvár 33(8): 382-383.

SzÉKY, P. (1978): SzERGEJEV, B.: Isznak-e a halak? Búvár 33(11): 525.

SzÉKY, P. (1979): STERBETZ, I. (szerk.): Élő örökségünk: génerózió, génbank. Búvár 34(5): 237.

SzÉKY, P. (1980): Az állatokról leleplezően: LÁNYI, Gy.: Meglepő dolgok állatokról. Búvár 35(5): 229.

SzÉKY, P. (1980): PETERS, G.: Vergleichende Untersuchung zu Lautgebung einiger Feliden (Mammalia, Felidae). Állattani Közlemények 67(1-4): 128-129.

SzÉKY, P. (1980): REMMERT, H.: Ökologie - Ein Lehrbuch. (Springer Verlag, Berlin-Heidelberg-New York, 1978). Állattani Közlemények 67(1-4): 129-130. 